\title{
Introduction: Towards a History of Indic Philology
}

Philology was everywhere and nowhere in premodern India, and this is a problem that demands the attention of anyone interested in the global history of this form of knowledge. That it was everywhere can be established by a broad set of criteria: among them, the evidence of manuscript production and reproduction; the millennia-long history of the disciplines of language science and hermeneutics; and a commonly-held set of textual and interpretive practices seen in the works of authors who lived and worked in disparate times, places, languages, and fields. That it was nowhere is equally apparent: the civilization of classical and medieval India - that time-deep cultural and social complex whose principal but not exclusive linguistic medium was Sanskrit-produced no self-conscious account of philology (indeed, it lacked a word for it altogether) and, compared to other Eurasian culture-areas like Western Europe, the Arabic ecumene, or the Sinitic world, never witnessed any sort of crisis of textual knowledge which would issue into a set of general theory of textual authenticity and reliability. On this view, Indic civilization produced literati and scholars in great abundance, but no philologists.

An anecdote perfectly captures this apparent asymmetry. When Georg Bühler, arguably the greatest Indologist of the Victorian period, was in the midst of his tour in search for manuscripts in the valley of Kashmir in 1875, he encountered a "most objectionable habit," in which manuscripts were "not unfrequently [sic] 'cooked,' i.e. the lacunæ and defects in the original are filled in according to the fancy of the Pandit who corrects them." He continued,

I was asked by my friends if the new copies to be made for me were to be made complete or not; and one Pandit confessed to me with contrition, after I had convinced him of the badness of the system, that formerly he himself had restored a large portion of the Vishnudharmottara. [In the case of the Nilamatapurāna,] the Mahârâja of Kaśmîr was the innocent cause of the forgery. He ordered Pandit Sâhebrâm to prepare a trustworthy copy of the Nilamata for edition. As the Pandit found that all his Mss. were defective in the beginning, and as he knew from the fragments, as well as from the Râjatarainginî what the lost portions did contain, he restored the whole work according to his best ability. If I had not come to Kaśmîr soon after his death, it is not improbable that the genuine text would have 
disappeared altogether. For the Pandits thought, until I convinced them of the contrary, Sâhebrâm's copy greatly superior to all others. ${ }^{1}$

Bühler was as genial and sympathetic a student of classical India as any, and this was by no means simply Orientalist hauteur. He admits that a similar lack of integrity had been the norm until quite recently in Europe, dating the emergence of the "historico-critical method" to the "end of the last [i.e. the eighteenth] century." All the same, the anecdote has acquired the status of a fable, a just-so story of Indic traditionalism's lack of philological scruple, even in its best representatives.

A more hermeneutically or ethnographically charitable view of this situation suggests itself, that the kind of creation-through-transmission typified by Bühler's Kashmiri informants was a coherent way to orient oneself towards a textual corpus and thus a kind (or a 'mode') of philology in its own right. Such a view would have comparable cases from Europe and elsewhere to recommend it, and it would also be able to ally itself with the now oft-voiced critique of the positivism underlying just the sort of "historico-critical" methods that Bühler presumed to be so self-evidently superior. In the context of contemporary debates in the humanities on the pluralization and globalization of knowledge, such a presumption could be understood to embed within it a host of concealed assumptions about the relationship between the history of European knowledge and of knowledge produced elsewhere, which by its very asymmetry was complicit in the reproduction of political, social, and institutional powerBühler, after all, wrote as a functionary of the colonial state. ${ }^{2}$

The present study of the modes of philology which were practiced in medieval southern India begins from a position similar to this. It is centered on the recovery of habits of reading, thinking, and writing that were earlier analogues

1 Georg Bühler, Detailed Report of a tour in search of Sanskrit mss. made in Kaśmîr, Rajputana, and Central India (London: Trubner and Co, 1877), 33, with his emphasis and scheme of transliteration; earlier, Bühler had described the same Sahebrām's son, Dāmodar, as the "one really distinguished Pandit" he met with during his travels (26).

2 For an example of this line of thinking, attempting to recover the range of epistemic options plowed over by a self-aggrandizing colonial modernity, see Walter Mignolo, The Darker Side of the Renaissance: Literacy, Territoriality, and Colonization (Ann Arbor: Michigan University Press, 1995), esp. 8-25 (an overview of the place of philology in the practice of a 'pluritopic hermeneutics') and 125-216 (two extended case studies of the interaction between Nahuatl and Hispano-Latin forms of knowledge). A more recent and abstract restatement can be found in Madina Tlostanova and Walter Mignolo, "On Pluritopic Hermeneutics, Transmodern Thinking, and Decolonial Philosophy," Encounters 1, no. 1 (2009). 
to those practiced by Sahebrām and his fellow Kashmiri Pandits. Nevertheless, its argument is distinct from this broadly postcolonialist line of thinking in a number of ways. While I presume that knowledge and scholarly practice are imbricated in wider schemes of power, this imbrication is not understood to be a monopoly of the modern or the colonial; nor does it take this one historical moment to be the sole locus of epistemic transformation, contestation, and disruption. On the contrary, another such transformative moment can be located in time and place considered here, the far South of the Indian subcontinent over a roughly two hundred year period stretching across the common era's twelfth, thirteenth and fourteenth centuries. These spatial and temporal restrictions are informed by the limits of my own linguistic competence and study; as these were very eventful centuries, I hasten to emphasize at the outset that this is only a partial picture of the spectrum of textual scholarship there undertaken.

I argue that the south Indian philology of this period was transformed as a direct result of the creation of new corpora of anonymous Sanskrit texts. These embodied practices which-for all their difference from the textual methods of the post-classical West, and for all their similarities to the habits which were castigated by Bühler-present an internally consistent set of interrelated modes of philology. These philological methods were framed, expanded, and refined via the production of a huge number of new texts, classed under the ancient genre titles of tantra and purāna, which entered into circulation in the South from the middle of the eleventh century. These new textual corpora in turn supplied an intellectual catalyst and a body of source material that fed back into the practices of more traditional works of scholarship, to novel and dramatic effect. The larger point that this book aims to document and describe is that the genres, scholarly tools, and methods of argument that were diagnostic of this particular kind of philological practice raise important questions about the enterprise of the history of philology more generally.

\section{Philology?}

It will likely not come as a surprise to any readers of this book that philology is enjoying a moment of recuperation. From the several well-known "returns" to it announced over the last few decades, through the efforts-concretized in this publication series-to reflect upon and so ensure its future, to the recent publication of a popular-scholarly history of its life in the Anglophone world, philology is receiving some overdue attention as a central part of the humanities and the history of knowledge more generally. This is not the place 
to review the circumstances that have led to this moment, nor to survey all of the positions staked out within it: tracking the bibliography of reflections on philology has become a philological task in its own right. ${ }^{3}$

But first of all, of what do we even speak when we speak of philology? A great many definitions have been mooted, over a period of centuries, and these have been diverse in their presumptions and sometimes contradictory in their ramifications. I take as a starting point a recent attempt at a definition by Sheldon Pollock, who has suggested that we understand philology tout court to be "the discipline of making sense of texts," which "is and always has been a global knowledge practice, as global as textualized language itself." ${ }^{\prime 4}$ Some might wish to offer a more specific definition, or to claim that philology is something that we need to keep within a tightly maintained set of historical, cultural, or linguistic parameters to have it be of any analytic use. For my part, I find much that is commendable in this attempt to formulate such a broadly comparative, minimalist definition, one that is deliberately framed in light of the situation in we students of the non-European past now find ourselves. This definition, moreover, served as a guideline for a notable effort by Pollock and a group of his collaborators to produce a survey of the global range of past philologies. This pioneering effort of juxtaposition supplies the condition of possibility for a study like the present monograph.

All the same, Pollock's proposed definition can be sharpened in several ways.

First of all, the texts with which a potential philologist concerns herself are both prior and plural. This is perhaps an obvious point, even a truism; nevertheless, certain significant entailments follow from it. It is only in light of some preexisting set of texts that philology can, properly speaking, operate. While a philologist may of course bring her attention to bear on a single work produced

3 Pollock's "Introduction" to World Philology, ed. Sheldon Pollock, Benjamin A. Elman, and Ku-ming Kevin Chang (Harvard University Press, 2015) contains an especially useful survey; Jerome McGann's A New Republic of Letters (New York: Harvard University Press, 2014) and James Turner's Philology: The Forgotten Origins of the Modern Humanities (Princeton, NJ: Princeton University Press, 2015) both appeared too recently to be included there; it is the latter that I refer to as a recent integrative history of the subject. Another recent and very significant statement, Lorraine Daston and Glenn W. Most's "History of Science and History of Philologies," (Isis 106, no. 2 (2015): 378-390), is discussed in the Conclusions.

4 Sheldon Pollock "Future Philology? The Fate of a Soft Science in a Hard World," Critical Inquiry 35, no. 4 (2009): 934. This may be usefully supplemented by the same author's recent review article ("Indian Philology and India's Philology," Journal Asiatique 299, no. 1 (2011)) of Gérard Colas and Gerdi Gerschheimer, eds. Écrire Et Transmettre En Inde Classique (Paris: École française d'Extrême-Orient, 2009), and by Pollock's most recent statement on this theme ("Philology and Freedom," Philological Encounters, Vol. 1 (2016)). 
by a contemporary (what used to be called 'literary criticism'), the epistemological backing of a collection of preexisting texts is a logical as well as practical necessity. Practically, this depends on an act of delimitation, the creation of a corpus or a set of corpora within a wider preexisting field, in order to supply the particular sphere in which the philologist is able to go about her business of making sense. This does not imply that the philologist must by definition be a historian or even a historicist: the presumption of priority does not entail any particular set of causal or metaphysical criteria. The adherents of Mīmāṃsā ('The Inquiry'), among premodern India's most precocious philological theorists and practitioners, presumed their target corpus to exist outside of time and causality altogether. But it was the Mīmāmsakas' principled decision to delimit their enquiries to the Veda that made possible their exegetical perspicacity; and it was this that in turn motivated other kinds of old Indic philologists (among them, jurists and theorists of poetry) to adopt and adapt the Mīmāmssakas' methods.

The second of my suggested alterations to the minimalist model concerns technique. Pollock's definition, in its effort to make the franchise of potential philologies as expansive as possible - to let a hundred philological flowers bloom - risks overextension, and the confusion of philology with simply reading. Any literate is in some sense committed to the pragmatic project of "making sense" of a given text, whether it be lyric poem or café menu, learned treatise or children's storybook. Philology is expressly and exclusively a form of virtuoso reading, reading as a methodical, self-aware and self-reflexive practice. Further, it is reading performed in public, whether in teaching or in the production of a text of one's own. It is this insistence on the public nature of philology-as both understanding and communicative practice-that serves as a principal check upon collapsing it into just reading as such.

Philologists, virtuoso professional literates working in some sort of intersubjectively available arena, practice an intensified mode of reading, one that consists of a shifting congeries of specific and stipulable methods and practices. Such a mode of reading, moreover, could vary within a given era or within the norms of a particular genre; indeed, in Indian premodernity it could often vary within the works of a single author. ${ }^{5}$ So as historians of philology, we

5 Cf. Gerard Colas, “Critique et Transmission des Textes de L'Inde Classique," Diogène 186 (1999): 49 (his emphasis): "L'éventail des critères de choix des leçons comme leur hiérarchie relative dépend des disciplines en question [...] Faudrait-il donc distinguer plusieurs critiques textuelles indiennes en fonction des genres littéraires? En fait, l'utilité d'une telle distinction reste relative. Le même commentateur, surtout lorsqu'il domine bien plusiers disciplines, recourt, d' une page à l' autre, à des arguments très différente: il fait flèche de tout bois." 
cannot specify in advance one type of virtuoso reading - e.g. the kind that seeks to assess textual variation, or that presumes the workings of an authorial intention - to be philological and any other to be non-philological. On the contrary, a multitude of different philological techniques existed and coexisted (not always happily) within specific social and institutional contexts. Like all human activities, these changed over time through the interventions of particular agents, in the service of particular projects. Any global history of philology needs to acknowledge and to account for this technical variability, while retaining the epistemic openness that is the most salutary feature of a minimal definition such as Pollock's. In fact, in retaining such a minimal definition, we open up the possibility of this one form of knowledge providing a base of operations, as it were, to think about the global history of knowledge more generally.

\section{Indian Philology?}

But can we write a history of premodern Indic philology? It is notoriously difficult to reliably locate early Indian texts and authors in space and time, and nowhere is this more the case than in Sanskrit, the putatively timeless language of the gods, and the language of most of the materials I will review here. As such, attempting to present Sanskrit philology diachronically — and thus attempting to chart patterns of change over time-might seem like an exercise in tentative conjecture, if not in pure imagination. ${ }^{6}$ But this problem of evidence is less troubling than a more fundamental lexical and conceptual difficulty, and this must be confronted at the outset. There simply is not a term or a concept for 'philology' in Sanskrit or Tamil or in any other historical South Asian language, with the important exception of Persian. ${ }^{7}$ What we may delineate as the category of 'philological practice' was scattered over a broad range

6 Colas ("Critique et Transmission", 54) concludes his commendable overview of premodern Indic textual criticism by acknowledging the lack of firm chronology to be "le plus grand obstacle" to a more detailed history.

7 See Kinra "This Noble Science: Indo-Persian Comparative Philology, c. 1000-180o CE" in South Asian Texts in History: Critical Engagements With Sheldon Pollock, ed. Yigal Bronner et al. (Ann Arbor: Association of Asian Studies, 2011), who renders the Arabic loan 'ilm-i lughat as "science of philology" (371); Kinra, however, focuses upon Persophone philological scholarship (in fact, lexicography) from a considerably later period, in the seventeenth and eighteenth centuries CE. A fuller version of Kinra's argument has recently appeared: "Cultures of Comparative Philology in the Early Modern Indo-Persian World," Philological Encounters, 1 (2016). 
of scholarly genres, intellectual disciplines, and life-ways, lacking any sort of conceptual or institutional center that might provide the minimal conditions for a history. To begin, as it were, before the beginning, it is useful to scout out some of the lexical contexts in which we might conceive of an Indic (or a Sanskritic) philology, despite the evident absence of a single equivalent. By beginning this way, I am not so much interested in arguing for a counterfactual history ("what would they have called it had they given it a name?"); nor do I wish to chart a cultural or civilizational lack (as in the interminable debates over historicality in classical India). Instead, I seek simply to lay out some of the implicit conditions of the thought-world of medieval India's textual scholarship.

In Sanskrit, there are at least two possibilities for an equivalent for 'philology' as I have tentatively defined it, as the public and methodical practice of virtuoso reading. The first of these is ryākhyāna, 'exposition' or 'explication'. This term appears as an already-established principle in Patañjali's Mahābhāsya ('Great Commentary,' perhaps 2nd century ВСЕ) on the foundational grammatical sūtras of Pānini. Insisting that the grammar included subtle indications (jñāpakas) of the details of its teaching, Patañjali invokes the first of his system's explanatory metarules or paribhāṣās: vyākhyānato viśeșapratipattir na hi sandehād alakșanam, "The understanding of a particular detail derives from explication, for a rule does not fail due to uncertainty about it." Here, vyākhyanna - a word which by its morphology signals its affinity to the discipline of grammar, vyākarana, itself-has a predominantly pedagogical sense, and thus neatly captures what I have suggested is philology's public or communicative dimension. It is only through the explication du texte that the student can gain insight into the inner workings of the grammatical system. Given the primacy accorded to grammar throughout the long history of Sanskrit literary culture and its vernacular congeners, this early attestation of the need for interpretative unpacking might be understood as a warrant for textual scholarship more broadly. But this early injunction, however influential, never provoked any second-order reflection (a vyākhyāna śāstra, so to say) on how this might be performed. ${ }^{8}$

8 A partial exception to this can be seen in the set of tantrayuktis or 'interpretative strategies' that are referred to in a cluster of diverse early treatises in Sanskrit, notably the Arthaśästra on politics and the medical authors Caraka and Suśruta, as well as exerting a notable influence on grammatical writing in Tamil: see V.K. Lele, The Doctrine of the tantrayukti-s: Methodology of Theoretico-Scientific Treatises in Sanskrit (Varanasi: Chaukhamba Surabharati Prakashan, 1981) and Jean-Luc Chevillard, "The Metagrammatical Vocabulary inside the Lists of 32 Tantrayukti-s and its Adaptation to Tamil: Towards a Sanskrit-Tamil Dictionary," in 
In fact, the very precociousness of certain kinds of textuality in Sanskrit may have short-circuited such reflection. It is the stuff of general cultural history that the archaic ritual and hymnic cycle of the Veda is called śruti or 'the hearing', in reference to its wholly oral-aural transmission and the supposed self-evidence of its content, as directly available and reliable as the data of one's senses. It was to these which the earliest forms of knowledge were directly attached as the 'limbs of the Veda' or vedāngas: phonetics, prosody, grammar, etymology, liturgics, and astral science. These in turn were grouped within a further, diverse body of works - initially also oral-aural, and subsequently reduced to writing - that augmented, expanded upon and complemented the śruti corpus. These were the smrti or 'memory,' which also included such central cultural monuments as the Mahäbhärata epic and the law code attributed to Manu. Such a diverse and prodigiously early textual ecologyin which specialist vyākhyāna seems to extend all the way down, like so many tortoises - might have foreclosed the possibility of imagining a comprehensive practice of virtuoso reading and interpretation. More to the point, the oralaural prejudices built into this system, and the astonishing feats of mnemotechnic which sustained these prejudices, seems to have forestalled systematic thinking about works of language whose historical life was grounded in textartifacts, despite the certain cultivation of writing and formal literacy for millennia in India. ${ }^{9}$

The other candidate in Sanskrit for a conceptual counterpart to 'philology' falls within the scope of vyutpatti. This is a complex lexeme which in its most basic sense means something like 'development' or 'cultivation'. It describes the linguistic practice of etymology or verbal derivation on the one hand (as in the Mahāryutpatti, the "Great Work on Etymology," an early ninth-century Sanskrit-Tibetan dictionary ${ }^{10}$ ), and on the other, a process of language learning and scholarly self-fashioning (where its sense is perhaps closest to 'education' or 'Bildung'). Vyutpatti is something that was performed, whether onto a lexical item or onto the consciousness of a student: this draws attention to the methodical dimension of philological practice that I have emphasized, as well as sharpening the sense of philology as an ethical art or a way of life. Encompassing both the technical-practical and intellectual and moral dimensions

Between Preservation and Recreation: Proceedings of a workshop in honour of T.V. Gopal Iyer, ed. Eva Wilden (Pondicherry: Institut Français de Pondichéry/École Française d' ExtrêmeOrient, 2009). My thinking here is indebted to discussion with Gary Tubb.

10 See Pieter Verhagen, A history of Sanskrit grammatical literature in Tibet, Vol. 1: Transmission of the canonical literature (Leiden: Brill, 1994), $15 \mathrm{ff}$. 
of scholarship, vyutpatti captures something important; however, sustained reflection on the term is vanishingly rare.

The only domain of which I am aware where the word became a significant term of art is in the early history of alamkāaraśästra or poetic theory. As with the priority of vyäkhyanna in grammar, vyutpatti was present at the creation of the discipline of poetics. In the preamble to the earliest surviving work of selfconscious literary theory, Bhāmaha's Kāryālaṃkāra (On the Ornamentation of Poetry, before $\left.700 \mathrm{CE}^{11}\right)$, the author includes his initial self-questioning about the need for a formal treatise on his chosen subject. Bhāmaha introduces the view of unnamed others, for whom the beautification of utterances consists solely in the proper cultivation of nominal and verbal forms (supām tiñäm ca vyutpattim vācām vāñchanty alaṃkrtim ); this is in turn is equated with 'fine language' (sauśabdyam) as such (1.14-15). He goes on to pair this strictly linguistic understanding with an equal attention to the nature of meaning: vyutpatti thus remains for him strictly within the canons of grammatical usage. Writing polemically in Bhāmaha's wake, the slightly later poet and theorist Danḍin staked out a different interpretation, grounded in vyutpatti's semantic ambiguity: "Learned men, with an eye to people's cultivation, have composed the procedure for the crafting of language, which possesses a variety of styles." ${ }^{12}$ Ratnaśrijjñāna (ca. 950), Daṇ̣in's earliest and most perspicacious commentator, adopting Dandin's own word in his previous verse, understands vyutpattih as gunadosavivekah, the ability to distinguish good from bad, and takes pains to emphasize that the act of literary interpretation contributes to the wider cultivation of moral awareness. Showing his own Buddhist confessional proclivities, Ratna writes,

One can profit greatly due to just the description of, say, a king who understands virtue, and from the meaning of this [description], one can attain both the morally good and happiness. What this amounts to saying is that there is no human goal that does not arise due to literature, provided that its basis has been properly understood. ${ }^{13}$

11 See Yigal Bronner, “A Question of Priority: Revisiting the Bhāmaha-Daṇ̣in Debate," Journal of Indian Philosophy 40, no. 1 (2012) on Bhāmaha's floruit and his relationship to the other earliest surviving theorist, Dạ̣̣in.

12 Kāvyādarśa 1.9: ataḥ prajānām vyutpattim abhisandhāya sūrayah | vācāṃ vicitramārgāa ṇām nibabandhuh kriyāvidhim ||

13 Ad loc: gunajñarājādi [varnanāto py arthāti] śayaprāptis tadarthāc ca dharmah sukham ca sampatsyete. kiṃ bahunā so 'sti puruṣārthạ kaścit yah kāryāt parigṛhītāśrayān na jayate. (the bracketted text is the editors Thakur and Jha's conjectural restoration). For 
In the work of the maverick literary theorist Rājaśekhara (ca. 90o), vyutpatti made its closest approach to becoming a master-concept. The fifth chapter of his Kāryamīmāmsā (called kāryapākakalpa, "The Process of Perfecting Poetry") explores the distinction between ryutpatti and pratibha $\bar{a}$ (poetic 'genius' or 'imagination') and seeks to assess the relative value of each in the formation of a poet. ${ }^{14}$ As is typical in Rajasasekhara, the chapter's method is forensic, and several definitions of vyutpatti are mooted: received scholarly opinion defines vyutpatti as 'extensive learning,' necessary for a poet to discuss a wide range of themes. To this, Rājaśekhara himself, extending Daṇ̣in, retorts that it is 'the discrimination of the proper from the improper.' Here learning is joined to judgment, in a way that is suggestive of a broader intellectual and ethical program, a promising start for a more general theory. ${ }^{15}$ Later in the same chapter, invoking a now-lost authority named Mañgala, Rājaśekhara ends up returning vyutpatti to its status as just 'fineness of language' or sauśabdyam, simply returning to the point from which Bhāmaha had commenced centuries earlier. Thus, while his discussion of vyutpatti (and his invocation of prior opinion of it) is intriguing, Rājaśekhara's understanding of the term was at best inchoate; for him, as for every other poetic theorist, vyutpatti wavered between its technical-etymological and educative senses. Perhaps owing to this very semantic instability, vyutpatti never gained currency as a general covering term for the professional cultivation of language, whether among the älaṃkärikas or elsewhere.

Neither of these two lexemes, nor their equivalents in the Indian vernaculars, can thus be claimed as a conceptual pair-part to philology. This lack of a single conceptual center is indicative of a still greater proliferation were we to attempt a social history of philological practice. The agents responsible for philology as it was actually performed in premodern India range over the anonymous emending scribe (that Great Satan of modern textual criticism), the village schoolmaster, and the itinerant päthaka or reciter, through to the canonical commentators, literary critics and authors of independent treatises. The ongoing work of these and other agents would have been sustained

Ratnaśrījñāna's date see Sheldon Pollock, "Ratnaśrījñāna," in Encyclopedia of Indian Wisdom: Prof. Satya Vrat Shastri Felicitation Volume, ed. R.K. Sharma (Delhi: Bharatiya Vidya Prakashan, 2005).

14 For a compelling interpretation of pratibhā, the other side of Rājaśekhara's distinction, see David Shulman, More than Real: A History of the Imagination in South India (Cambridge: Harvard University Press, 2012), esp. 80-89.

15 Kāryamìmāṃsā, 26: bahujñatā vyutpattir ity ācāryāḥ. sarvatodikkā hi kavivācah [...] ucitānucitaviveko vyutpattir iti yāyāvarīyah. 
everywhere by the silent majority of Indian textual culture, the individual readers and possessors of text-artifacts, the more or less learned and enthusiastic bibliophiles who produced and consumed the enormous majority of writing. These men (and some women), though not themselves philologists in the sense adopted here, were legatees of philologists' professional skills, the connoisseurs of their successful elucidations of textual meaning, and the reproducers of their corruptions and blunders. Our sense of all of these agents tends only towards the anecdotal: there exists nothing like a sociology or phenomenology of reading in this world. This is not to say this is impossible, simply that it has never been attempted. ${ }^{16}$

To be certain, this absence of a term-counterpart for 'philology' is troubling. So too is the difficulty of plotting, however tentatively, a social or institutional location for the performance of self-conscious textual scholarship, of the sort supplied by the medieval European monastery and university, or by the examination systems of the Sinitic world. I am tempted nevertheless to ascribe the lack of a ready-to-hand lexical and conceptual equivalent to philology to something like a famous aperçu of Margaret Mead's, that if a fish were an anthropologist, the last thing it would discover would be water. Mead may have meant this self-deprecatingly (or dismissively): in this case, however, the men who swam through the currents of early India's philological practices seem not to have needed to abstract themselves away from their labors with the text in such a way. Philological discipline appears to have been so integral to the life-world of those élite literates to whom we owe India's textual archive that to name it as such may have simply been superfluous. ${ }^{17}$

\section{Existing Studies}

This absence of an emic self-understanding has colored attempts by Indologists to understand and explain premodern Indian philology. In keeping with the larger rehabilitation of philology across the academy, the last decade has

16 A partial exception to this can be found in Paul Griffiths, Religious Reading: The Place of Reading in the Practice of Religion (New York: Oxford University Press, 1999), 114-129, which thoughtfully and provocatively argues for the dominance of the oral-aural over the text-artifactual dimension of classical and medieval Indic pedagogy and scholarship. Concentrating on the possibly non-representative world of the Buddhist monastery, Griffiths claims that a text-object was likely to have served as a stage prop for traditional instruction, rather than being actively consulted.

17 Cf. Pollock, "Introduction", 16, who cautiously frames a similar hypothesis. 
seen an increasing attention to the topic. Focusing on just a few recent contributions, on those materials focusing on Sanskrit, and oversimplifying considerably, two major trends can be distinguished. The first of these has attempted to characterize the editorial practices and the methods of text-constitution of early Indian scholiasts, in order to recover a prehistory of philological technique; the second, more hermeneutical trend has sought to historicize individual acts of textual understanding, and to situate these within particular reading communities.

Plotting the direction of the first of these trends, a pioneering study by R.S. Bhattacharya surveyed a diversity of commentarial and scribal habits seen across a spectrum of śāstric, epic, literary, and technical works. ${ }^{18}$ Bhattacharya did not live to complete a full study of the phenomenon, but his well-annotated essay documented the awareness of textual corruption and its causes, the relative value assigned to different manuscript sources, and other fundamental technical criteria for a lectional criticism, present throughout Sanskrit textual culture. Drawing on Bhattacharya, among others, Colas' brief but comprehensive article tacks between the evidence of manuscript copyists and the more or less formalized procedures of commentators in constituting their roottexts. His conclusions are sobering: the inconsistencies and contradictions of doctrine-between the desire to preserve and the need to harmonize, thus between faithful transmission and conjecture-were so strong, and the diversity of actual practices of criticism so great, that a coherent positive account of early Indian philology is extremely difficult to synthesize. ${ }^{19}$

More optimistic is Olivelle's account of the textual criticism practiced by the medieval southern scholiast Haradatta, writing on the aphorisms on dharma attributed to Âpastamba. Olivelle extensively demonstrates that not only was Haradatta an empiricially thorough student of the available tradition of Âpastamba, likely collating both manuscript and oral transmissions of the work, but that the commentator's methods were in fact more scrupulous, and his proposed emendations more sensible, than those of his most strident 19th century Indological critic, whose willful perchant for hasty textual repair Olivelle contrasts with Haradatta's own methods. ${ }^{20}$ Meanwhile, the editorial recovery of

18 Ram Shankar Bhattacharya, "Use of Manuscripts in Textual Criticism by our Commentators," in Sampādana ke Siddhānta aur Upādāna (Principles of Editing and Instrumentation), ed. V.V. Dwivedi et al. (Sarnath: Central Institute of Higher Tibetan Studies, 1990).

19 Colas, "Critique et Transmission", see further the quotations given above, nn. 5 and 6.

20 Patrick Olivelle, "Sanskrit Commentators and the Transmission of Texts: Haradatta on Āpastamba Dharmasūtra," Journal of Indian Philosophy 27 (1999); see also idem, "Unfaithful Transmitters: Philological Criticism and Critical Editions of the Upanișads," Journal of 
the earliest version of Vallabhadeva's commentary on Kālidāsa's Raghuvaṃśa has revealed a terse gloss far less discursive than the other scholia attributed to the early tenth-century Kashmirian. ${ }^{21}$ While eschewing questions beyond their own philological work, the editors Goodall and Isaacson show that this sort of scholarly apparatus was subject to extensive revision and expansion by later hands, while also supplying evidence of the ways in which emendation of the poet's text were driven by the priorities of a later theoretical consensus. ${ }^{22}$

Sheldon Pollock's recent synthesizing discussion of literary and Vedic commentary needs to be seen alongside these contributions, especially insofar as Pollock's is the first attempt to offer a historical periodization of India's philology. Departing from the close synchronism between the emergence of commentarial writing on Sanskrit belles-lettres in the works of the selfsame Vallabhadeva and on the Mahābhärata epic at the hands of renunciate-scholar Devabodha (possibly dating to the early eleventh century and, like Vallabha, a Kashmirian), Pollock proposes the gradual efflorescence of surviving commentarial writing to be not an artifact of textual survival but "an actual intellectualhistorical transformation," one that would reach its zenith in fourteenth cen-

Indian Philosophy 26 (1998) for a fuller account of Otto Böhtlingk's interventionism. Olivelle's reasoning here is by no means an appeal to a fetishization of tradition: on occasion (e.g. "Sanskrit Commentators," 567 and n. 44 ), he is more than happy to accept the great St. Petersburg scholar's judgement, provided that it withstands scrutiny.

21 Dominic Goodall and Harunaga Isaacson, eds. The Raghupañcikā of Vallabhadeva, Being the Earliest Commentary on the Raghuvamiśa of Kālidāsa Vol. 1 (Groningen: Egbert Forsten, 2003).

These changes to Kālidāsa's text, the majority of which relate to grammatical adjustments to the source and target of similes in response to the latterday strictures of alaṃāraśāstra, are discussed in Dominic Goodall, "Bhūte 'āha' iti pramādāt: Firm evidence for the Direction of Change Where Certain Verses of the Raghuvamiśa are Variously Transmitted," Zeitschrift der Deutschen Morganländischen Gesellschaft 151, no. 1 (2001) and more recently in idem, "Retracer la transmission des textes littéraires à l' aide des textes 'théoriques' de l' Alaṃkāraśāstra ancien," in Colas and Gerschheimer, Écrire Et Transmettre. The massive incursions, which the editors find in the transmission of Vallabhadeva (first diagnosed by Goodall in his announcement of the edition), produced a far more 'user-friendly' version of the commentary than the text initially published by the Kashmirian. This echoes West's dictum on the scholia of the classical world: "Commentaries, lexica, and other works of a grammatical nature were rightly regarded as collections of material to be pruned, adapted or added to, rather than as sacrosanct literary entities" (Martin Litchfield West, Textual Criticism and Editorial Technique applicable to Greek and Latin Texts (London: B.G. Truebner, 1973), 16). As Goodall convincingly demonstrates, however, this process of incursion ended up crucially degrading the integral text of Vallabha, and often obscuring the reading which he had before him. 
tury South India in the realization of the vast project of exegesis of the Vedic corpus attributed to Sayyana. ${ }^{23}$ Drawing on earlier work, Pollock details the process of recension, emendation, and athetization that animated this scholarly practice; but where Colas, with similar materials, saw an unreconcilable confusion of methods, Pollock's view of such eclecticism is more optimistic: this embodied "a model of textality at once historicist-intentionalist and puristaestheticist—standards that, if obviously contradictory, are perhaps not fatally so." 24

Similar in intent is Pollock's attention to the understanding of larger-order phenomena of textual meaning evinced, if only occasionally, by premodern commentators. This links his work with the second major trend of the Indological reconstruction of past philological habits, the attempt to recover practices of exegesis and interpretation, rather than text-critical establishment. A landmark for this second trajectory is the collective work of Tubb and Boose. ${ }^{25}$ Though this purports to be primer for students, in fact it contains the most detailed grammar, as it were, of the philological practices of Sanskritic India ever published. This is the pinnacle of the decades-long recuperation of the intellectual and cultural-historical value of the interpretations contained within traditional scholarship; to this may be joined the extensive citations and discussions of interpretations embedded in the apparatus of the ongoing Rāmāyana translation project of Robert Goldman and his collaborators. ${ }^{26}$ Efforts at recovering commentarial interpretations, especially but not exclusively those of literary commentary, have become a small subfield, especially in North America. ${ }^{27}$ Though in many cases this scholarship has not explicitly

23 Sheldon Pollock, "What was Philology in Early Modern India?" in World Philology, 133 (cf. 116).

24 Pollock, "What was Philology," 122.

25 Gary Tubb and Emery Boose, Scholastic Sanskrit: A Manual For Students (New York: American Institute for Buddhist Studies, 2007).

26 See most recently, and most extensively, Robert Goldman et al., trans, The Rāmāyaṇa of Vālmīki: An Epic of Ancient India. Volume 6: Yuddhakāṇ̣̂a (Princeton, N.J.: Princeton UP, 2009); see also Goldman, "How fast do monkeys fly? How long do demons sleep?" Rivista di Studi Sudasiatici 1 (2006).

27 To instance only a few representative and recent works: Ajay Rao, Refiguring the Rāmāyaña as theology: a history of reception in premodern India (Abingdon: Routledge, 2015) extends Goldman et al's interest in the Rāmāyaṇa epic to its South Indian theological interpreters; Lawrence McCrea has provided what is perhaps the most compelling account of the constitutive intertextuality of the literary commentary ("Poetry in Chains: Commentary and Control in the Sanskrit Poetic Tradition," in Language, Ritual, and Poetics in Ancient India and Iran, ed. David Shulman (Jerusalem: Israel Academy of Sciences 
understood its object to be philology, in the sense argued for here, that is precisely what it is. To take only a single and admittedly extraordinary example, what was the industrial-level production of exegesis on Śrīharșa's twelfth century masterpiece, the Naișadhìya, if not philology? Thanks to the work of Deven Patel, we can see for the first time how this text, easily and deliberately the most recondite in the whole of the canon of the mahākārya ('major poem'), elicited a range of interpretative responses from the straightforward and explanatory to the bravura, and produced as argumentative a field of partisans as any philological speciality ever. ${ }^{28}$

All of this work has been of an extremely high scholarly caliber, from which I have learned a great deal; this bodes well for further studies in the philological practices that South Asia's textual archive can yield up in such possible abundance. A common thread uniting nearly all of this scholarship has been its nearly exclusive attention to the commentary as the locus of philology. ${ }^{29} \mathrm{Of}$ course, this makes a great deal of sense. If philology is in fact both "the making sense of texts" and the public practice of a methodical virtuoso reading, then the work of commentators would seem to be the most logical place to look for it. Commentators, after all, read closely and widely, and left a paper trail as to the nature of this reading; and in South Asia, this paper trail is an enormous one. Moreover, in looking for an editorial logic (or illogic) in their ways of assembling their textual objects, Indologists do their premodern predecessors the honor of regarding them as their peers, to be assessed on their merits in a way that is at least analogous to how one might review the work of a contemporary. Given the

and Humanities 2010)) while Yigal Bronner and McCrea, in an essay on the alternate versions of a passage in a key canonical mahākārya, have produced the most detailed close reading yet to appear that take into account both issues of text constitution and hermeneutics ("To Be or Not to Be Siśupāla: Which Version of the Key Speech in Māgha's Great Poem Did He Really Write?" Journal of the American Oriental Society 132, no. 2 (2012)). Outside of the domain of literary exegesis, see Richard Nance's innovative study on the commentarial habits of late first millennium Mahāyāna Buddhism (Speaking for Buddhas: Scriptural Commentary in Indian Buddhism (New York: Columbia Univeristy Press 2012)). See Deven Patel, Text to Tradition: The Naișadhiyacarita and Literary Community in South Asia (New York: Columbia University Press, 2014), especially 81-130; in his concluding remarks to this discussion (129-130), Patel foregrounds the commentators' philology.

To be sure, there are exceptions: Colas ("Critique et Transmission", 51) discusses the critical testimony of Veṅkațanātha's Pāñcarātrarakșā, one of the texts discussed in the present work, while Pollock ("What was Philology", 123-124 and "Future Philology", 941-943) gives an appreciative précis of the argument of a seventeenth century philological 'monograph' by Melputtūr Nārāyaṇa Bhațțatīri, the Apāniniñyaprāmāṇyasādhana ("A Demonstration of the Validity of Non-standard Sanskrit"). 
fact that the explicit standard-bearers of philology as a discipline tend today to be textual editors, this focus makes even more sense.

Yet there is something to this focus that is reminiscent of the joke about the man who lost his keys in the park on the way home from a night's drinking, and was found looking for them under the streetlamp since "that's where the light is". Surely we can discover things about early Indian philology from what we can recover of the habits and ideas of copyists and scholiasts, and surely these things are of interest. But should we be prepared to broaden the scope of our search for the practices of textual sense-making - if we look outside the circle of the streetlamp - there is much that awaits our discovery. This book is meant to serve as an initial attempt. It looks, first of all, at texts that have not previously been considered as philological at all, certainly not in the same way that Vallabhadeva or Haradatta would be so considered. The suggestion that we reframe the purānas and tantras created in South India in the first several centuries of the second millennium as works of philology is not meant to be willfully contrarian; still less is it meant to subserve an indigenist or nativist effort to delegitmate the critical and historical philology that is the basis of Indological practice. By recovering the philological impulses that these works contained we are made aware, in the first instance, of the ways in which certain past people set about making sense of their own local textual universe. The three independent studies that comprise the bulk of the book enable us to trace in great detail the diversity of further varieties of philology which were enabled by this-logically and chronologically precedent, but ongoing and contemporaneous - production of tantric and purānic works.

This is an account, then, of intellectual and cultural historical change, of how new ways of thought and writing were produced in one very delimited context. In order to enter into this particular space and time, some broad introductory parameters are necessary. These are needed in order to sketch in some of the broad historical, material-practical, and ideological circumstances presumed in the chapters that follow. It is to these that I now turn.

\section{Parameters}

Consider, for a moment, the sheer quantum of manuscript text-artifacts in South Asian languages that have survived to the present: easily seven million manuscripts, and possibly as many as thirty million, ${ }^{30}$ numbers which defini- 
tively put to rest any notion of the epiphenomenal status of the writing in this world. Faced with this, we could simply presume the existence of textual scholarship, even absent any sort of emic theory of it. But the history of the written word and the concern with it as a matter of specialist preoccupation can be pushed back further in time than just the remnants that have survived to the present: in particular, the history of textuality can be broadly correlated with what we know of the history and periodization of Indic society more generally.

Over the last several decades, the period around the turn of the first millennium of the Common Era has sloughed off most of the opprobrium with which it had been laden by colonial and post-colonial scholarship alike. These centuries had been seen by high Orientalist historiography as the final, decadent period of 'Hindu' impotence faced with the coming of Islam; this view was in turn supplanted — though with its implicit value judgments retained intactby a subsequent historical materialist scholarship which saw in them the setting for the feudal cashiering of India's society and economy. The spectres of these lapsed consensuses continue to haunt the study of what has come to be called the 'early medieval' period of South Asian history, but the contributions made by recent historical scholarship have been profound. The subcontinent as a whole is no longer seen as a site of a one-way process of social and economic devolution but as a complex network of heterogeneous but interrelated political and circulatory spaces. ${ }^{31}$

Although it has never been seen in this way, a prime index of southern Asia's burgeoning economic and social development in this period can be gauged through its textuality. The early second millennium witnessed the growth in absolute terms of the sheer amount of textual production, the velocity of its

eds., Manuscript Cultures: Mapping the Field (Berlin: De Gruyter, 2015); the high end of the spectrum is the number adduced by the late David Pingree.

An excellent recent review of this historiographical situation can be found in Daud Ali, "The historiography of the medieval in South Asia," Journal of the Royal Asiatic Society 22, no. 1 (2012). On high orientalist scholarship, refer to Ronald Inden, Imagining India (Bloomington: Indiana University Press, 1990), 117-122 (medieval 'Hinduism' as the causative agent of decline) and 185-188 (the Dark Ages view of medieval polity). The feudal mode of production thesis continues to command serious adherents in the modern Indian academy, and has produced an enormous scholarship: a classic statement is D.D. Kosambi, An introduction to the study of Indian history (Bombay: Popular Prakashan, 1956), while B.D. Chattopadhyaya, The Making of Early Medieval India (Delhi: Oxford University Press, 1997) represents an intelligent and sophisticated critique of this position from within its own intellectual horizons. Andre Wink, Al-Hind: The Making of the Indo-Islamic World. vol. 1 (Leiden: Brill, 1990) provides a useful political-historical framework expressly aimed at supplanting the dichotomies of earlier scholarship. 
circulation, and its social and spatial pervasion. While our awareness of this can be in part attributed to the adventitious fact of preservation, the many data we possess suggest a wider pattern of change. Much valuable evidence can be gathered thanks to the efforts of researchers and cataloguers working the world over; especially significant is the remarkable work of the NepalGerman Manuscript Cataloguing Project (NGMCP), jointly based in Hamburg and Kathmandu. Some tentative conclusions can be ventured by adopting as a sample those palm-leaf manuscripts catalogued by the NGMCP which have been securely assigned dates in the common era (to date, approximately 1100 individual texts): after a handful of ninth and tenth century manuscripts, there is a jump in the eleventh century (forty-three texts) and then a considerable expansion in the twelfth and thirteenth centuries (around a hundred and ten texts each; the three centuries thus account for roughly twenty-four percent of the sample). These data are admittedly wholly anecdotal, both owing to the isolation of the Nepal valley in southern Asia and to the vagaries of both manuscript survival and the NGMCP's ongoing work of cataloguing. But they jibe with what can be seen elsewhere, for instance with Bühler's reference to "the numerous ancient palm-leaf Mss. from Gujarāt, Rājputāna, and the northern Dekhan, the date of which run certainly from the 11th, and possibly from the 1oth century" (thus trending somewhat earlier), or with L.B. Gandhi's survey of the Jain collections at Patan, in which "of the dated manuscripts there are about a dozen written in the 12th century and one hundred in the 13th century" (thus somewhat later). ${ }^{32}$

The collections in particular regions need to be situated in networks extending the length and breadth of the subcontinent, within which the individual text-artifact moved rapidly and far. An example of this can be seen, once again in the Kathmandu collections, in the form of a copy of the as-yet unpublished Siddhāntasārapaddhati of King Bhoja of Dhārā, in what's now the Indian state of Madhya Pradesh, roughly fourteen hundred kilometers to the southwest. This manuscript was written in the local Newari script and dated to the year 197 of the Nepalese era (or $1078 \mathrm{CE}$ ), less than a generation after the end of the king's reign around 1055: this copy was thus possibly the transcript of an exemplar produced in its royal author's lifetime. ${ }^{33}$ The movement of individ-

32 G. Bühler, Indian Paleography. Translated by John Faithfull Fleet. Appendix to The Indian Antiquary 33 (1904) 85; L.B. Gandhi, ed. A catalogue of manuscripts in the Jain bhandars at Jesalmere, compiled by C.D. Daläl (Baroda: Central Library, 1923), 40.

I derive my information for this manuscript (NAK 1-1363) from the NGMCP's exemplary online archive (http://134.100.72.204/wiki/B_28-29_Siddhāntasārapaddhati, accessed 15 April 2012). 
ual literati, often across vast distances, suggests that a case like this was far from anomalous. Another complementary index of the secular growth of textual production can be found in the expansion of epigraphical corpora, most prodigiously in the case of the Tamil country under the Cola kings, in whose regnal years nearly twenty thousand inscriptional texts are dated, themselves only the surviving remnants of a far more widespread documentary order of deeds, land assessments, wills, and legal judgments. ${ }^{34}$ These data, grounded in material culture, in turn suggest inferences about the social history of philology in this period: seen in the light of the history of early medieval South Asia, we can suppose that an expanding and intensifying frontier of agriculture and a growing population made possible a proliferating specialist class of literates, including virtuoso literates like professional philologists.

The changes of this period, however, were not just quantitative; the practice of textual study seems to also to have transformed. Evidence of this is furnished by the emergence or reconfiguration of new textual genres. Perhaps most significantly, as already mentioned, this period witnessed the creation of the literary commentary; both the poetic anthology and the legal digest seem to also have their origins then. ${ }^{35}$ But bulking largest, both physically and in terms of its wider significance, is the emergence of a habit of encyclopedism. This begins in

34 A recent authoritative survey argues that, out of a corpus of roughly 28,000 Tamil inscriptions issued over the period $300 \mathrm{BCE}-1900 \mathrm{CE}$, around 19,000 can be assigned to the tenth through the thirteenth centuries, the period of Cola ascendency, imperial dominance, and decline (Y. Subbarayalu, South India Under the Cholas (Delhi: Oxford University Press, 2012), 18).

35 On the literary commentary, see again Pollock, "What was Philology", 116-118. The earliest surviving anthology is Vidyākara's Subhāșitaratnakośa (ca. 1100 CE): its significance was noted by its editors Kosambi and Gokhale in their introduction (xxix-xxxix, noting the existence of earlier collecteana) and by its translator in his (Daniel H.H. Ingalls, trans. An anthology of Sanskrit court poetry: Vidyākara's "Subhāșitaratnakośa." (Cambridge, Mass: Harvard University Press, 1965), $30 \mathrm{ff}$ ); the appreciation of this has only increased in the years since (Pollock, The Language of the Gods in the World of Men (Berkeley, California UP, 2006), 114-116). The remarkable labors of Ludwik Sternbach established the importance of the anthologies for the literary history of Sanskrit more generally: see especially his $A$ descriptive catalogue of poets quoted in Sanskrit anthologies and inscriptions (Wiesbaden: Harrassowitz, 1978-1980). On the legal digest, see Robert Lingat, The classical law of India (Berkeley, University of California Press, 1973), 115-122, who dates the beginnings of the genre to the work of Lakșmīdhara (first half of the twelfth c.). This periodizationwhich remarkably coincides with Vidyākara's lifetime-was taken up in a speculative way some years ago by Pollock, who suggested that the geographical provenance of the nibandha works could be mapped onto the advancing frontiers of Turkic expansion in the subcontinent, a hypothesis that still awaits serious exploration (Sheldon Pollock, "Deep 
the eleventh century, and was a major transformation in the study of major literary genres and scholarly disciplines, which were by this time many centuries old. ${ }^{36}$ This constituted a census, consolidation, extension, and application of textual knowledge across fields, often leading to enormous bibliographic and discursive treatises, like Abhinavagupta's Tantrāloka (Kashmir, ca. 1020), Bhojadeva's many works, including the aforementioned Siddhāntasārapaddhation Śaiva ritual or his Śrnigāraprakāśa on literary theory (Malwa, ca. 1010-1050), ${ }^{37}$ Someśvara's Mānasollāsa on everything from cooking to poetry to battlefield horoscopy (northwest Deccan, completed 1128), and Ballālasena's Dānasāgara on gift giving in all its permutations (Bengal, ca. 1170). In their published form, these works and those like them can run to many volumes - as manuscripts they take up many multiples of codices. These were not the more or less accidental agglomerations of material, but rather deliberately structured works, cross-referenced and indexed, invoking (whether directly or indirectly) what amounts to a library of source-texts. These are thus fundamentally philological, many of them — as three of the four named above — ascribed to royal authors, and so suggestive of well-functioning court ateliers of librarians, copyists, and

Orientalism?" in Orientalism and the Postcolonial Predicament, ed. Carol Breckenridge and P. van der Veer (Philadelphia: University of Pennsylvania Press, 1993), 105-106).

$3^{6} \quad$ I reluctantly leave unexplored here the question of the pan-Eurasian history of this move to the encyclopedia form: for contemporaneous Arabic and Persian encyclopedism, see the essays in Gerhard Endress, ed. Organizing knowledge: encyclopaedic activities in the pre-eighteenth century Islamic world (Leiden: Brill, 2006) and now Elias Muhanna, "Encyclopaedism in the Mamluk Period: The Composition of Shihāb al-Dīn al-Nuwayrì's (d. 1333) Nihāyat al-Arab fī Funūn al-Adab." (PhD dissertation, Harvard University, 2012); several of the essays collected in Florence Bretelle-Establet and Karine Chemla, eds., Qu'était-ce qu'écrire une encyclopédie en Chine, special issue of Extrême-Orient, ExtrêmeOccident 1 (2007) speak to the Sinitic world in this period. The conjunctural peculiarities of the political and cultural history of Latinate western Europe, above all the widespread institutional collapse and cultural involution of the end of the Roman imperium, provoked a prodigiously early habit of encyclopedism relative to other Eurasian culture-areas: Isidore of Seville's Etymologiae, the paradigmatic case, was completed in the early seventh century. Significantly, however, the early second millennium saw the first movement towards encyclopedic knowledge in the European vernaculars: Brunetto Latini's Livre du Trésor was completed in the final decades of the thirteenth century. Ann Blair, Too Much to Know (New Haven: Yale University Press, 2010) is an excellent overview-cross-cultural in ambit, though focusing on western Europe — of the long history of information overload and the means to remedy it.

37 See Whitney Cox, "Bhoja's Alternate Universe," Journal of the Royal Asiatic Society 22, no. 1 (2012) for a discussion of the organizational principles at work in the Śrnigāraprakāśa. 
research scholars. The eleventh and twelfth centuries saw boom years for professional textual scholars; this was a boom, moreover, extending well beyond the precincts of royal capitals.

Equally significant, and bringing us into the time and space of which I want to speak in detail, is what we can gather of patterns of transmission and textual circulation across the length of the Subcontinent. Again, from about the mid-eleventh century, the transmission of and creative reaction to Sanskrit literature produced in the cultural hothouse of Kashmir in the far northwest can be seen in ever greater detail in the peninsula and in the far south. ${ }^{38}$ In just acknowledging the fact of the Kashmir-to-South India axis of transmission in this period, we bring into view remarkable feats of specialized labor and technical know-how. The selection and physical transportation of Sanskrit works along the extreme north-south axis of the subcontinent, the need for the transcription of texts written on birchbark and in the Kashmir-specific Sāaradā character to the several Southern scripts usually written on palm leaf - these would have necessitated a well-working network of circulation and distribution, along with the expert knowledge that made this all possible, and an audience of readers for whom all of this work was worthwhile. Significantly, this seems to have happened in a completely decentralized way; no southern king set the collection of Kashmirian texts in motion, no court or monastic scriptoria seem to have played a significant role in their dissemination.

These two trends- the new encyclopedism and the southern appropriation of Kashmirian Sanskrit - were on a practical plane highly philologically demanding, and were only possible because of the existence and cultivation of a professional skill-set: abilities in palaeography, criticial bibliography, sourcecriticism, and in the use and refinement of a sophisticated array of interpretative tools. These form a part of a conventional and recognisable bundle of philological practices, and we can easily assimilate these processes of collection, commentary, circulation, and recasting with the work of scholars in other times and places. These in turn supply the backdrop to other philological texts and practices that cannot perhaps be so easily assimilated to our tacit understanding of philology, and bring us to the matter of the current study.

The more exotic modes of philology traced in the pages that follow first found place in the creation of new corpora of anonymous works written in Sanskrit, the work of philologists who chose to conceal themselves behind the personae of divinities and other mythological characters. These texts, couched

38 For a sketch of these transmissional dynamics, see Whitney Cox, "Saffron in the rasam," in South Asian Texts in History, 177-201. 
as examples of the much older genre-types of purānas and tantras, included inter alia efforts to organize and rationalize antecedent texts; in doing so, they resembled the products of the encyclopedists who were their approximate contemporaries. Along with this organizing bibliographic impulse, these anonymous philologists also incorporated, recast, and at times outright plagiarized earlier works.

Relating themselves in complex ways to the proliferating disciplinary orders centering on the Hindu deities Viṣnu and Śiva, these scholars' and their texts' sectarian location is itself significant within the wider cultural and social world of the time. It was precisely this era that witnessed the enormous growth of the South Indian temple as a major feature of the physical and institutional landscape, a centrality that was to survive the collapse of the imperial state system of the Cola kings that had subtended its emergence. Already in the first rush of the creation of these new texts, dateable to the early decades of the 11oos, this anonymous mode of tantric and purānic philology provoked a response in authors writing in more conventional genres. An especially significant case of this, reviewed briefly in the next chapter, sees these techniques repurposed in a major work of Tamil religious epic.

This early appropriation was to prove prescient. As these new texts and their philologies became a part of the accepted textual ecology, they were to create problems as well as possibilities for more conventional élite scholarship. In the case surveyed in Chapter Three, the Bhāvaprakāśana or "On the Displaying of Literary Emotions" of Śāradātanaya, we encounter what appears to be a wholesale importation of the methods of these modes of philology into the fields of literary and dramatic theory. What at first glance appears to be the product of a scholarly naïveté, especially in light of the profound transformations undergone within these śästras elsewhere, in fact illustrates a complex process of intellectual and compositional triangulation, suggestive of the plural milieux of argument and textual creation in this time and place. Elsewhere, the presence of these philological methods occasioned even more complex reactions. Certain scholars possessed of a high-cultural literary and philosophical education were confronted by the evident need to justify the validity of these recent pseudepigrapha, while also adopting and adapting their methods. Two exemplary instances of this conjoint process of defense and appropriation provide the major case studies of the fourth and fifth chapters. Roughly contemporary, these present an initial study in contrast. A single technical monograph among the wide-ranging, multilingual oeuvre of the celebrated Vaiṣnava poetphilosopher Venkațanātha (known also by his sobriquet Vedāntadeśika), the Pāñcarātrarakșa à seems to present a conservative effort to police the canon of Vaiṣnava liturgical writing. In distinct contrast to the small library assigned to 
Veñkațanātha, the Mahārthamañjari is the sole surviving work of the antinomian Śākta-Śaiva Maheśvarānanda. A hybrid and deeply idiosyncratic text, the Mañjari’s most marked point of departure from the Vaiṣnava master's essay on canonicity rests in its claim to itself constitute at once a work of divine revelation and the product of a particular human author.

The contrasts between the two texts do not vanish under close inspection, yet commonalities do emerge. Above all, there is their indebtedness to the work of their anonymous philological forebears; both respond to and adapt the pseudepigraphical works' new ways of handling texts, in some ways that are explicit and some that are tacit, or posssibly unconscious. In this, we can see in vivo the ways in which exceptionally intelligent and widely-read men came to terms with the new scriptural and scholarly dispensation of post-Cola era. Further, this appropriation was filtered through these two authors' specifically literary education and interests, just as in the case of the dramaturge Śāradātanaya. Venkkațanātha was one of the most justly celebrated Sanskrit and Tamil poets of his time; Maheśvarānanda's work reveals a powerful investment-he called it àgraha, 'an obsession' - with poetry and poetic theory. This point of connection, overriding or perhaps undergirding the marked theological differences of these men and their systems, suggests avenues for historical study beyond religious or sectarian identity. Based on these substantive studies, I conclude by returning to the general questions with which it began, about the place of the Indic past in an emerging global history of philology. By tracing out two lines of general inquiry - philology's imbrication in politics and its status as a form of historically conditioned rational knowledge - the delimited empirical results of this research can suggest avenues whereby the textual scholarship of other times and place, including our own, may be better historicized and better understood.

There is one other mode of philology that needs to be introduced at the outset of this study: that of the philologist who is its author. I claim no special authority in this regard; my own practices as a reader are conventional, and very much a product of the scholarly culture in which I received my training. At the risk of seeming pretentious, it seems to me worthwhile that I unpack these conventions, such as I understand myself to adhere to them.

First of all, my reading is historicist, in that I presume that human creations, preeminently works of textual language, make the most sense in the terms they were conceived and received. Meaningfulness is something I understand to be contextually constituted and contextually constrained: men make their own texts, but they do not do so in circumstances of their own choosing. At the same time, diachronic accounts of change- of the innovations, alterations, 
and misprisions that befall works of human effort and imagination - are of central interest to me. Many modern philologists are concerned with discerning general patterns and so crafting lawlike generalities. As much as I admire and depend upon work like this, I do not work the same way. Instead, my level of attention tends toward the particularist, at the level of the isolable detail as an occasion for interpretation. The sort of reading I practice tends to focus on the individual word, phrase, trope or reference, with reconstructing its antecedents and plotting its entailments. Finally, I try to be transparent in my presumptions, my evidence, and my explanations. While this amounts to little more than obedience to the grade-school injunction to 'show your work', it is a necessary if not a sufficent criterion of the sort of philology I attempt here.

These three guidelines of my philological reading - history, detail, and transparency - have an unreconciled quality to them, of which I am aware. Of necessity, these restrict the scope of inquiry. In its boundedness within a delimited spatio-temporal range, this study is at odds with most of the previous work on early Indic textual scholarship discussed earlier. Where Bhattacharya or Colas or Pollock are prepared to range over centuries and across the subcontinent in their researches, I remain confined to one corner of South India, by and large to the work of three authors who may have been contemporaries. This was not done out of false modesty, still less from the Romantic caprice of trying to see the world in a grain of sand. If anything, this is grounded in the possibly misplaced ambition that this study, if it proves interesting enough, might provide the impetus for other philological historical ethnographies. More problematic is the way that the first of these guidelines - the discipline of historical context - pulls against the priorities of the formal and aesthetic unpacking of the detail. This tension results in an oscillation between two different levels or scales in the argument, between the particular occasion of evidence (the word, phrase, or sentence of which I attempt to make some sense) and the larger order of causality or significance, whether it be intellectual- or social-historical. I do not know if I have succeeded in tacking between these two very different scales; I did, however, try to do so in a way that is self-aware and, again, transparent.

Reflecting on my own mode or manner of philology leads me to a salutary awareness of the difference between this and the sort of methodical, public, virtuoso reading that was once practiced by the authors whom I study. There is a sobering side to this: a great, apparently insuperable distance separates my philology from those studied here. An especially useful way to figure this is in terms of brute materiality, in the form of the palm leaf texts that were the principle medium of the textual culture of the medieval south. To have been any sort of literate in medieval south India, much less a virtuoso professional reader, would have been to spend some substantial portion of one's life in 
their presence: to have experienced them as objects of desire, frustration, excitement, attachment, and occasional enlightenment. I've had moments of this myself, though only at a great distance. There is no surviving direct trace whatsoever of the material basis of the world of our authors: while the habits of writing in the precolonial South were to tenaciously endure into modern times, the texts produced in this time have all fallen victim to time, damp, and the white ant. The works studied here continued to be copied, as did at least some of their sources and the works of their contemporaries.

The precipice on which the survival of any given written work in this time rested is something of which these authors were very much aware: Śāradātanaya's habit of inventing citations and the perspicacity with which Venkatanātha would diagnose potential problems of textual interpolation both depend in their different ways on the endemic material instability of the texts. While other parts of southern Asia preserve manuscripts from many centuries earlier, the far south is a remarkably hostile environment for them; uncopied, a text could easily disappear without a trace in just a few generations' time. It is a tribute to the vigor of the region's textual culture-its silent majority of unknown copyists and readers-that anything survives at all; that works survive in such profusion is a remarkable human accomplishment. Still, it is with a sense of envy that I turn to such a model work on the Greek and Latin classical tradition as Reynolds and Wilson's Scribes \& Scholars, to read of this work copied at Monte Cassino in the 10oos, or of that autograph text of Petrarch (in many ways, Venkkațanātha's European doppelgänger). This material absence further stands in for the growing gulf which separates us from the world of traditional Indic learning more generally: there were doubtless never very many who went in for the kind of reading, thinking, and writing these works demonstrate, but there are fewer still with each passing day who can access it at all, much less understand it. This gulf that separates us from our late-medieval philologists is something we must keep before our eyes, as we attempt, however cautiously, to cast some light across it. 